\title{
Implementing Business Model Canvas for Cibinong Science and Technology Park
}

\author{
TOMMY HENDRIX ${ }^{1}$, ANANG HIDAYAT ${ }^{2}$, MAULUDIN HIDAYAT ${ }^{3}$ \\ ${ }^{1}$ Research and Development Division for Technology Information, Indonesia Institute of Sciences, Bandung 40132, Indonesia \\ ${ }^{2}$ Center for Innovation, Indonesia Institute of Sciences, Bandung 40132, Indonesia \\ Email correspondence: tommy.hendrix@gmail.com
}

\begin{abstract}
The purpose of this study is to discuss about the design of business models Cibinong Science and Technology Park (CSTP) based on the position of CSTP managed by government agencies should be subject to formal rules and regulations in force. CSTP predictable business model design can operate with more flexibility than the existing business model today. CSTP business model design is expected to provide value not only to entrepreneurs (tenant), but also for the environment CSTP in order to manage the business with a healthy and sustainable. The method used in this research is descriptive approach by utilizing the framework Business Model Canvas (BMC) which is used to assess some business model variables at the Science and Technology Park (STP). The analysis shows that the management team CSTP have to revisit the structure of employment and work organization and the design of the operation, and CSTP can identify the target and the type of services or products needed. Further, CSTP should make a proposal which includes how to generate and deliver value, an important resource that CSTP have and what key activities should be developed for the future.
\end{abstract}

Key words: Cibinong Science and Technology Park, Business Models, BMC Frameworks.

\section{Penerapan Proses Bisnis Model Canvas pada Cibinong Science and Technology Park}

\begin{abstract}
Abstrak
Penelitian ini membahas tentang perancangan model bisnis untuk Cibinong Science and Technology Park (CSTP) dengan mendasarkan posisi CSTP yang dikelola oleh instansi pemerintah, dan harus tunduk pada peraturan dan peraturan formal yang berlaku. Tujuan yang ingin dicapai dalam penelitian ini adalah pengembangan desain model bisnis CSTP yang dapat diprediksi dapat beroperasi dengan lebih fleksibel daripada model bisnis yang ada saat ini. Desain model bisnis CSTP diharapkan bisa memberi nilai tidak hanya bagi wirausahawan (penyewa), tetapi juga untuk lingkungan CSTP agar bisa mengelola bisnis dengan sehat dan berkelanjutan. Metode yang digunakan dalam penelitian ini adalah pendekatan deskriptif dengan menggunakan framework Business Model Canvas (BMC) yang digunakan untuk menilai beberapa variabel model bisnis di CSTP. Hasil analisis menunjukkan bahwa tim manajemen CSTP harus meninjau kembali struktur kerja dan organisasi kerja dan perancangan operasi, dan CSTP dapat mengidentifikasi target serta jenis layanan atau produk yang dibutuhkan. Selanjutnya, CSTP harus membuat proposal yang mencakup bagaimana menghasilkan dan memberikan nilai, sumber penting yang dimiliki CSTP dan kegiatan utama apa yang harus dikembangkan untuk masa depan.
\end{abstract}

Kata kunci: Cibinong Science and Technology Park, Kerangka BMC, Model Bisnis 
Jurnal Bisnis \& Manajemen, 2018, Vol. XIX, No. 1, 47-58

Available at: $h t t p: / / j o u r n a l . f e b . u n p a d . a c . i d / i n d e x . p h p / j b m$

\section{INTRODUCTION}

There is no definition of STP that can be universally accepted (Hansson, Husted and Vestergaard, 2005). However, one definition that is often used is the definition of STP developed by the International Association of Science Parks and Areas of Innovation (IASP, 2002); "STP is an organization managed by certain professionals whose main objective is to improve the welfare of the community by promoting a culture of innovation and the competitiveness of businesses related to the knowledge-based institutions. To enable this goal is achieved, then the Science Park (SP) stimulates and manages the flow of knowledge and technology amongst universities, $\mathrm{R}$ \& $\mathrm{D}$ institutions, companies and markets; SP facilitates the creation and growth of innovationbased companies, including high-quality space and facilities".

Formation of STP has become a phenomenon that evolved from spontaneity to the serious planning that started from the US, then Europe, Southeast Asia, South America and Africa (Ondategui, 2001). For more than 60 years of evolution since the emergence of the first STP, diversity goals, promoters, actors, models and even the title has to reflect a complex reality, and it is often difficult to obtain in a single definition (Adam, 2012). Many terms have been made to the STP initiatives, but they are still converging under the common name of the Science and Technology Park (STP). UNESCO (1993) states that the term STP includes any type of cluster of high-tech as Technopole, Science Park, Science City, Science Town, Cyberpark, Research and Technology Park, Science and Technology Park, Technology Park, Technology Incubator, Technopark and Technology Business Incubator. Meanwhile, lately the term STP developed into the most common terms used by academic and special literature (Ondategui, 2001).

STP Association has made its own definition, some of the most commonly used definitions, such as for example; United Kingdom Science Park Association, (UKSPA, 2012): Science Park (SP) is a business support and initiatives for technology transfer that encourage and support start-ups and incubation of innovation advanced, high-growth, knowledge-based businesses, provide an environment in which businesses a larger and international businesses can develop specific
JURNAL BISNIS \& MANAJEMEN

ISSN 1412 - 3681

and close interactions with specialized centers of knowledge creation that is mutually beneficial, and has formal and operational relationships with centers of knowledge creation such as universities, institutions of higher education and research organizations. Meanwhile, the National Association of Entities Promoting Innovative Enterprises (ANPROTEC, 2012) promote that Technology Park (TP) is a complex of productive industry and services based on science and technology, planned, characterless, centralized and cooperative, which gathers companies whose production based on technology developed at the research center linked to R\&D. TP is a promoter effort to take the culture of innovation, competitiveness, business improvement training, based on transfer of knowledge and technology, in order to increase production for the well-being of an area. Meanwhile, the Association of Science and Technology Parks of Spain (APTE, 2012) stated that STP is a project, generally associated with the physical space, with the following characteristics: (a) formal and operations associated with the university, (b) research centers and higher education institutions, which are designed to encourage the creation and growth of knowledgebased enterprises and other organizations that have a service sector, usually formed at STP itself with an added value and the governing body stable that promote the transfer of technology and foster innovation among companies and organizations. In general, the development process of the STP trying to bring together in one space, users and consumers of knowledge with the aim of provoking a key synergies and facilitate the flow of knowledge and technology among all the organizations that are part of the community (Link, 2009).

The Cibinong Science and Technology Park (CSTP) is an area in Cibinong Bogor, West Java Province which is designed for the implementation of the technology transfer process intellectual property and research and development of Lembaga IImu Pengetahuan Indonesia (LIPI) to the public in order to contribute to improving the economic and regional competitiveness. CSTP has a function as a center to promote technology development, technology incubators and centers and information technology services. It shows that the CSTP tend to be referred to the definition of United Kingdom Science Park Association, (UKSPA, 2012), which provides business support in the form of 


\section{JURNAL BISNIS \& MANAJEMEN}

ISSN 1412 - 3681

initiatives for technology transfer in order to encourage start-ups through the incubation of innovation, providing support for knowledge-based businesses, providing an environment in which business larger and international businesses can develop specific interactions and close to the center in the creation of knowledge are mutually beneficial, and has formal and operational relationships with centers of knowledge creation such as universities, institutions of higher education and research organizations that exist. Thus, it is important to design business models CSTP to be more effective, efficient and targeted.

In designing the CSTP business model will be based on five fundamental business challenges, namely, (1) why the business is not developed?; (2) what is wrong with the business ?; (3) how to get great results from current business; (4) how to grow the business ?; and, (5) what can be done to develop the business?. Of the five challenges will basically lead to the one thought, namely; business strategy that can be designed for the future target and what the organization business in the future segmentation. So, it is necessary to study the development of a business model that is right for CSTP the considerable business challenges as mentioned above.

This paper was written mainly to deliver implementing business model canvas as a review on the interactive business programs that being develop and process of performance in facilitating commercialization Reseach and Development results in CSTP area. It means similarity to lift up government policy to enhance capability from a program that offers during accumulate activities process especially from new technology-based companies.

The questions above are sometimes difficult to answer because it does not have the tools for the business portrait. To evaluate the business plan or the ongoing business, it is necessary to look at from the standpoint of a clear and complete about the business model. While the Business Model Canvas (BMC) is one tool to assist in more accurate view of how such a business is or will be undertaken (The Business Channel, 2016). With these tools seemed to see the business of the big picture, but still full and detailed what the key elements associated with the business. Thus it will show the whole picture was very helpful
Jurnal Bisnis \& Manajemen, 2018, Vol. XIX, No. 1, 47-58 Available at: http://journal.feb.unpad.ac.id/index.php/jbm

in answering questions about the business. Thus, the purpose of this study was to analyze the business model CSTP approach BMC which also evaluated one by one of the key elements of its business to be more easily analyzed further what is less precise, and could eventually take strategic steps in achieving business goals of CSTP.

\section{LITERATURE REVIEW}

\section{Science and Technology Park (STP) Model}

Attempts to classify the STP in a context that is defined conducted by Rowe (1987). Rowe identified three main models of Science Park in the UK according to the university's involvement in the project, each also defines a different model of organizational management. Kang (2004) provides five models of STP according to its management organization, namely: 1) based on the university; 2) is directed by the central government or local governments; 3 ) created and managed from an inter-institutional agreement; 4) promoted by real estate developers on its own initiative; and, 5) driven non-profit organization which was primarily aimed at revitalizing the local economy Lately, IASP (2010), led by Luis Sanz has created a new classification method is more complex that widen the existing typology. This method is known as 'Strategigram', which is a software-based tool that allows managers to analyze STP Park its strategy, assess its evolution and compare it to other Park's strategic profile. This tool is an STP profile cut by 7 axes: localization, position on the flow of technology, the target enterprise, degree of specialization, target market, networking and management models.

\section{Business Model}

The business model is a concept that has grown and has tried to define from time to time. Osterwalder, Pigneur and Tucci (2005) affirms that the concept of business model that appeared for the first time in an academic article in 1957 and then in the title and abstract papers in 1960 but only became popular in the 1990s. In the review made by Zott, Amit and Massa (2011) analyzed the presence of the term business model in a variety of different publications, during the period 1975 to 2009. The results show that the attention focused on the concept that met between 1995 and 2010. Once this concept started studied in more detail by the scientific community 
Jurnal Bisnis \& Manajemen, 2018, Vol. XIX, No. 1, 47-58

Available at: $h$ ttp://journal.feb.unpad.ac.id/index.php/jbm

and entrepreneurs. Clarification process started trying to define the concept in different studies and in the academic and scientific publications. Osterwalder et al. (Osterwalder, Pigneur, and Tucci, 2005) defend the view that where, through a review of significant number of publications studying the evolution of the term business model, which enables it to conclude that the terms used are often linked to the internet but not exclusively refer to it. For the purpose of clarifying the process of evolution of the business model, by displaying definitions and classifications more sequential and integrated different authors expressed about the concept of the business model. Osterwalder et al. (2005) based on an extensive review of the literature focuses on the concept of a business model in which rarely mentions the term. With the proposed evolutionary phase, stated that the research business model has matured over the years. Although researchers have not leaned on each other's work and findings extensively, certain progress can be observed (Osterwalder, Pigneur, and Tucci, 2005).

The concept of "business model" is widely used in the business world, but academic research on the subject is still rare (Wang, Net and Wallin, 2009). The literature shows that the business model is often discussed topics superficially and often without understanding its roots, its role, and its potential (Wang, Net and Wallin, 2009).

To allow classifying literature widely business model, a review is made by Zott et al. (2011), revealed that its main business model has been done in trying to answer or explain the following three phenomena: (1) e-business and the use of information technology in organizations; (2) strategic issues such as the creation of value, competitive advantage, and the company's performance; (3) innovation and technology management.

On the other hand, most scientists do research business model without a clear definition of the concept. According Zott, Amit and Massa (2011), (37\%) of the publications that were analyzed did not define the concept altogether. Nearly half (44\%) explicitly define the term 'business model' with its main component count. In each publication fifth authors refer to the work of other scientists in defining
JURNAL BISNIS \& MANAJEMEN

ISSN 1412 - 3681

the concept. Table 1, below summarizes some of the most valid definition of the term 'business model'.

Table 1. Definition of a Business Model

\begin{tabular}{|c|c|c|c|c|}
\hline No & Author & Year & $\begin{array}{c}\text { Description of Business } \\
\text { Model }\end{array}$ & $\begin{array}{l}\text { Business Model } \\
\text { Component }\end{array}$ \\
\hline 1 & Timmers & 1998 & $\begin{array}{l}\text { The Business Model is } \\
\text { The Architecture of The } \\
\text { Product or Service and } \\
\text { The Flow of Information } \\
\text { that Includes Actors, } \\
\text { Benefits And Revenue. }\end{array}$ & $\begin{array}{l}\text { Architecture; } \\
\text { The flow of } \\
\text { information; } \\
\text { Benefits for actors; } \\
\text { Revenue. }\end{array}$ \\
\hline 2 & $\begin{array}{l}\text { Mahade } \\
\text { van }\end{array}$ & 2000 & $\begin{array}{l}\text { The Business Model is } \\
\text { Based on Three Main } \\
\text { Streams, Namely Players, } \\
\text { Revenues And Logistics. }\end{array}$ & $\begin{array}{l}\text { Flow value; The } \\
\text { flow of income; } \\
\text { The folw of } \\
\text { logistic. }\end{array}$ \\
\hline 3 & $\begin{array}{l}\text { Afuah } \\
\text { and } \\
\text { Tucci }\end{array}$ & 2001 & $\begin{array}{l}\text { The Company utilizes } \\
\text { its Resources To Provide } \\
\text { Better Value For } \\
\text { Customers And In Return } \\
\text { Gain Profit, Therefore } \\
\text { The Company Should } \\
\text { Perform Better Than Its } \\
\text { Competitors Do. }\end{array}$ & $\begin{array}{l}\text { Linkage; } \\
\text { Customer Value; } \\
\text { Income. }\end{array}$ \\
\hline 4 & Morris et al. & 2005 & $\begin{array}{l}\text { Variable Current Group } \\
\text { Of Decisions Are } \\
\text { Interlinked With The } \\
\text { Strategy, Architecture } \\
\text { And Economics For } \\
\text { Sustainability. }\end{array}$ & $\begin{array}{l}\text { Economy; } \\
\text { Operational; } \\
\text { Strategic Model. }\end{array}$ \\
\hline 5 & Shafer et al. & 2005 & $\begin{array}{l}\text { Explains How To Create } \\
\text { And Capture Value In A } \\
\text { Value Network. }\end{array}$ & $\begin{array}{l}\text { Strategic options; } \\
\text { Creating value; } \\
\text { Capturing value; } \\
\text { Network value. }\end{array}$ \\
\hline 6 & $\begin{array}{l}\text { Johnson, } \\
\text { Christensen } \\
\text { and } \\
\text { Kagermann }\end{array}$ & 2008 & $\begin{array}{l}\text { The Business Model } \\
\text { Is Built On The Four } \\
\text { Elements Include The } \\
\text { Value Proposition, Profit } \\
\text { Formula, Processes And } \\
\text { Resources. }\end{array}$ & $\begin{array}{l}\text { The value } \\
\text { proposition } \\
\text { customers; } \\
\text { Profit Formula; } \\
\text { Resources key; } \\
\text { Processes key. }\end{array}$ \\
\hline 7 & $\begin{array}{l}\text { Osterwalder } \\
\text { and } \\
\text { Pigneur }\end{array}$ & 2010 & $\begin{array}{l}\text { The Business Model } \\
\text { Describes How To } \\
\text { Create, Transmit And } \\
\text { Capture Value By The } \\
\text { Organization. }\end{array}$ & $\begin{array}{l}\text { The Value } \\
\text { Proposition; } \\
\text { Target Customers; } \\
\text { Channel } \\
\text { Distribution; } \\
\text { Relationships; } \\
\text { Configure The } \\
\text { Value; Core } \\
\text { Competencies; } \\
\text { Network Partners; } \\
\text { The Cost } \\
\text { Structure; } \\
\text { The Revenue } \\
\text { Model. }\end{array}$ \\
\hline
\end{tabular}

Source: M. Suleman Sabir, Raja Mazhar Hameed Theoretical Foundation of Business Model and Their Building Blocks, 2012 [30]

Sabir and Hameed (2012) identifies 28 key block by reviewing the work of 62 writers about the business model from 1996 to 2010. Most scholars identify cash flows and the products or services provided by the company as an important element of its business 
JURNAL BISNIS \& MANAJEMEN

ISSN 1412 - 3681

model.

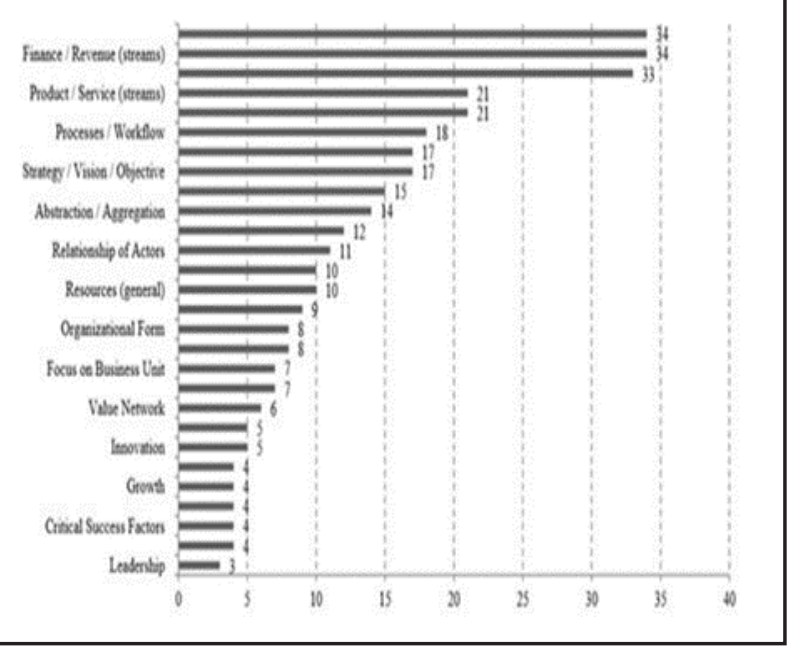

Figure 1. Business Model Block

\section{Business Models for STP}

Figlioli (2011) conducted various research libraries, but did not get the information that is packed with systematic that can answer questions about the business model STP. However, there are some authors who study the related concepts that somehow contribute to recognize the existence of the STP business model in an environment of innovation. They also contribute to understanding the importance of a mechanism to capture and deliver value to partners STP. Chesbrough and Rosenbloom (2002) defines the importance of the business model in capturing value from innovation and maintain that business organisation should really bring the technology to the market through a specific business model that explicitly or implicitly active role in innovation. Furthermore, they concluded that customers appreciate the technology to reduce costs and or create new possibilities and solutions to the real problem. Different customers may need different latent attributes of the technology. For that reason, it is stated that there is no single value that is inherent in the technology, the technology can be developed in a different way and may give different values. This allows conclusions from the complexity of the process of obtaining the value of the technology involving not only bidder, but also all the network components that define the value of supply and demand. To that end, an alignment is to identify the attributes of the technologies in which companies must focus
Jurnal Bisnis \& Manajemen, 2018, Vol. XIX, No. 1, 47-58 Available at: http://journal.feb.unpad.ac.id/index.php/jbm and be able to identify customer problems and how it will be resolved. Alignment can be done through the development of business models. Therefore, we can conclude that the relevance of having a business model in an organization such as STP, particularly when focused on aspects of the promotion of innovation and technology transfer.

Albahari, Perez and Klofsten (2011) identify gaps that may exist between supply and demand in business STP, and how this can be improved with effective ways of providing support at every business in terms of configuration (infrastructure, resources, proximity to institutions knowledge) and process (services and activities that add value). The final thing gives STP a responsibility to identify and define the real needs support from obligations, identifying characteristics and different levels of development. This will allow STP to provide enhanced value generating services and achieve improved performance. According to the authors STP business model should be based on networking and collaboration with external actors, as well as a strategic tool for companies that are connected to the same STP through partnerships and alliances for the company to gain access to various types of media and skills. Relevance of a more economical, Figlioli (2011) propose the relevance of the business model in the perspective of funding. Figlioli (2011) highlights the importance of input resources for the implementation and operation of the facilities and services that can be accepted by public and private funds. It's becoming more difficult to obtain due to a period of maturation in the early stages of the STP. As a result, in countries such as Brazil and Indonesia where there is a very high dependence for the STP of public resources, which may not be sustainable and led to uncertainty in the sustainability of the STP.

At this point, the business model has an important role. The business model reflects a different configuration of STP on issues such as actors, government, infrastructure, service and implementation as well as operations that set the stage and sets out how the management team STP create and deliver value to the company that is therein, shareholders and other stakeholders. This affects how the project is to promote the financial investment and other types of feedback. Therefore, we can conclude that the business model 
Jurnal Bisnis \& Manajemen, 2018, Vol. XIX, No. 1, 47-58

Available at: $h$ ttp://journal.feb.unpad.ac.id/index.php/jbm

is a tool for creating a strong base in facilitating the development of STP. Such a development would enable faster results received from the investment, and will promote the acceptance of new financing from private investment and reducing dependence on the public.

The outline design of a business model that has been running CSTP is, as can be seen in Figure 2 below.

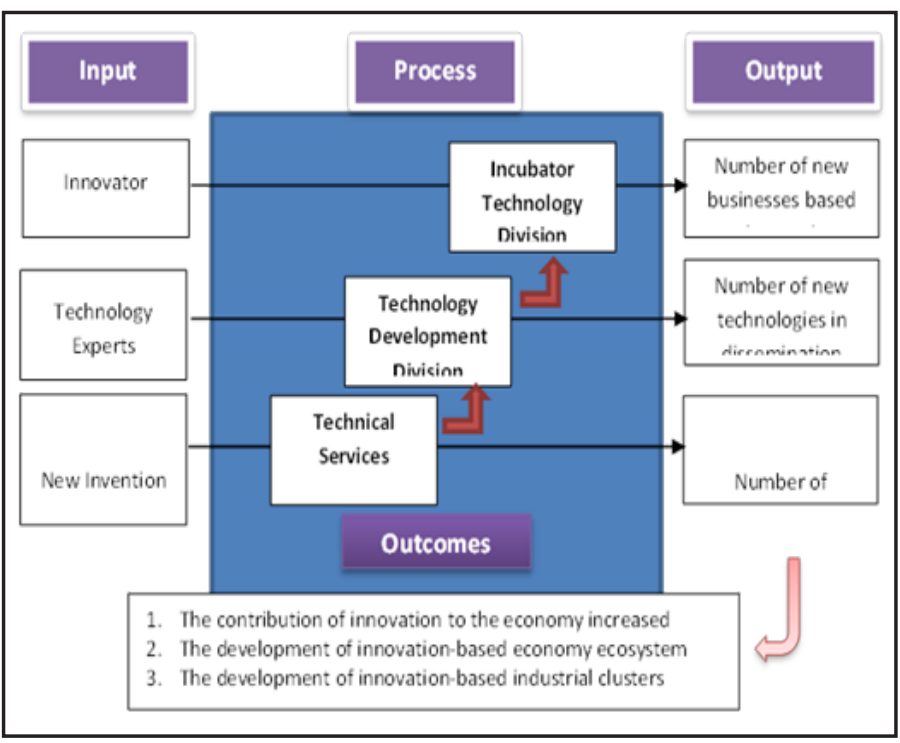

Figure 2. Business Model Design for CSTP

\section{Business Model Canvas (BMC)}

The businessmodel that can be offered as an alternative in the development of CSTP is the Business Model Canvas (BMC). BMC (The Business Channel. 2016) is a business model that consists of nine (9) blocks of area business activity. In each block of business activity has a goal mapped out a strategy in building a strong business, could win the competition and be successful in the long term. BMC is characterized by 9 block models which taken together will be a single business entity, namely: (1) Customers Segment; (2) Value Proposition; (3) Customer Relationship; (4) Channel; (5) Revenue Stream; (6) Key Resource; (7) Key Activities; (8) Key Partnership; (9) Cost Structure. Some factors of use in BMC are as follows:

\section{Visual Thinking:}

The best way to use the BMC is to print a large postersized version and paste it to the wall. Afterwards, founder using sticky post-it notes as to fill the nine parts. Sticky notes enable group thinking because everyone on the team can participate actively.

\section{Iteration quickly:}

"Iteration" is a process in which the founder of "out of the office or the lab" and attempts to validate the idea, then back again to the office to improve its business model and its products based on the feedback obtained from the market. With a quick and thorough nature of the business model of the canvas, the founder can quickly perform this iteration.

With a quick look at the association of nine business component:

Business Model Canvas allows the entrepreneur to visually illustrate the relevance of the individual components of the business. Often founder drawing lines and illustrations on the poster to represent the pieces of the puzzle and how they work together. In this way, the team can find the relationship of market opportunities and or a unique value proposition. Next, the team can then document the new ideas as new hypotheses to test BMC as a new iteration.

\section{Forcing teams to succinctly convey his thoughts:}

Because the information is recorded with a short on post-it notes, the team was forced to explain precisely and concisely what they want to test or follow up on the next iteration.

Visual form of business models facilitate startup canvas to share it with a partner, colleague:

Because the business model of the canvas is presented in the form of large posters and visual, easy to share via a photo or take the poster off the wall to meet with other interested parties.

\section{Advantages Business Model Canvas}

The BMC advantages in the application are as follows: First, can be used for all kinds of business models, travel, restaurants, hotels, plantations, mining and so forth;

Second, accelerate to determine the overall strengths and weaknesses of the business;

Third, process analysis and profit needs be done quickly;

Fourth, business Mapping to identify the weaknesses since the early and understand the business strength of the right viewpoint;

Fifth, mapping BMC systematically describe the business that can be used for decision making strategic management of business development.

\section{Implementation Business Model Canvas on CSTP}

BMC can be applied in a variety of business models, 


\section{JURNAL BISNIS \& MANAJEMEN}

ISSN 1412 - 3681

especially in the business that need to be initiated CSTP, the following are utilizing BMC on CSTP in a new business model or ongoing:

First, build Customer Relationships; BMC is important to build relationships with consumers CSTP. CSTP relationship with consumers is important that consumers benefit and increase loyalty.

Second, increase Sales; When the marketing strategy can be united through BMC, expected sales target can be achieved. Customer Segment, Channel, Customer Relationship (3 Blocks in BMC) has a goal to increase sales.

Third, dealing with Competitors; It is no less important when BMC has been executed is to build a solid business to deal with competitors. In this competitive business needs mapped CSTP further.

Fourth, ensure Business Running; Often confused situation faced in starting and running a business in the CSTP, in this BMC can include anyone who will support CSTP business to run. BMC is important to map out what is needed in order to keep the business running.

Fifth, having a Business System; BMC is an effective way to create a business system in the CSTP, the goal to make business more effective and can produce maximal benefit CSTP, although not routinely executing CSTP are in business, or change the management of the CSTP.

\section{METHODS}

These research papers were done by using a qualitative research methodology, with an approach where CSTP consolidated studied and analyzed to understand their business model empirically such as customer segments, value propositions, customer relationships, revenue streams, key resources, key activities and key partnerships. To fulfill this objective, a narrative review is done with data mining adapted from the generic business model as proposed by Osterwalder \& Pigneur (2009). Data mining done with approaches, by collect and synthesize literature consisting of reports, policy documents, journal articles, and unpublished sources. Table 2 below shows the block's business model and an explanation. The purpose of this study is to seek information related to research topics implementing business model canvas in CSTP. On the other side, reflecting
Jurnal Bisnis \& Manajemen, 2018, Vol. XIX, No. 1, 47-58 Available at: $h$ ttp://journal.feb.unpad.ac.id/index.php/jbm

a different configuration of STP on issues such as actors, government, infrastructure, service and implementation. This paper is expected become the input for a potential source of information in the development of science and technology, as well as the nature of the process implementation on CSTP business model.

Table 2. Adaption to Generation Business Model

\begin{tabular}{|c|c|}
\hline $\begin{array}{l}\text { Business Model } \\
\text { Block }\end{array}$ & Description \\
\hline Customer segments & $\begin{array}{l}\text { Define groups of different people or organizations. } \\
\text { STP aims to reach out and serve it. What type of } \\
\text { organization, business or institution that became the } \\
\text { focus of STP? For whom STP create value? }\end{array}$ \\
\hline Value proposition & $\begin{array}{l}\text { Bundle of products and services the STP offer } \\
\text { to its tenants? What are the advantages of } \\
\text { STP management by providing a link with the } \\
\text { organizations? Experiences to customers where the } \\
\text { STP solution aids? }\end{array}$ \\
\hline Channel & $\begin{array}{l}\text { How STP communicate and reach each customer } \\
\text { segment to deliver its value proposition? }\end{array}$ \\
\hline $\begin{array}{l}\text { Customer } \\
\text { Relationship }\end{array}$ & $\begin{array}{l}\text { Type STP building and maintaining relationships } \\
\text { with each customer segment. How STP offered his } \\
\text { services? }\end{array}$ \\
\hline Income stream & $\begin{array}{l}\text { Represent STP income of each customer segment. } \\
\text { Tenant pays for what? }\end{array}$ \\
\hline Key Resources & $\begin{array}{l}\text { Describe the most important asset that is required } \\
\text { to make the business model work. A key resource for } \\
\text { what the value proposition of STP want? }\end{array}$ \\
\hline Key Activities & $\begin{array}{l}\text { Describe the most important things that companies } \\
\text { should do to make the business model work. What } \\
\text { are the key activities that STP will need to send a } \\
\text { value proposition? }\end{array}$ \\
\hline Key partnerships & $\begin{array}{l}\text { Describe network of suppliers and partners to make } \\
\text { its business model work. What STP key partners } \\
\text { have? }\end{array}$ \\
\hline
\end{tabular}

\section{RESULTS AND DISCUSSION}

Business Model Canvas of CSTP (Application Details) First, business model as a method, then business model from the aspects of its components, and the business model as a business strategy. Meanwhile element in the Business Model Canvas (BMC) include Customer Segment, Value Proposition, Channel, Customer Relationship, Revenue Stream, Resources Key, Key Activities, Key Partnership and Cost Structure. To construct business models using this approach starts from the Customer Segment, followed by Value Proposition, Channel, Customer Relationship, Revenue Streams, Key Resources, Key Activities, Key Partners and Cost Structure. To develop this BMC, CSTP organization started from capturing condition at this time, followed by a SWOT analysis. SWOT analysis 
Jurnal Bisnis \& Manajemen, 2018, Vol. XIX, No. 1, 47-58

Available at: $h$ ttp://journal.feb.unpad.ac.id/index.php/jbm

can be used to design a prototype business model improvement and business models of the future.

The steps in the preparation of the Business Model Canvas CSTP is as follows:

\section{Customer Segment}

CSTP in running a business, an organization must first establish who is to be served. Organizations can set to serve one or more segments. Determination of the segment will determine the other components in the business model. The business segments of the CSTP are new entrepreneurs and new companies that are and will be in operation. Based on the record of cooperation that has been done, a potential customer segments for CSTP is strategic industries such as power generation industry. Most industrial power plants installed in the 1980s - 1990s. Thus the life span of today, especially the control system, has reached the age known as obsolescence. The industry's dependence on foreign products considered to be very high, especially support for spares and support expertise in the country. CSTP with technology development segment, which is supported by the facilities and resources available is able to offer services to evaluate or assess the decision making retrofit, propose a replacement control system and ordinances replacement. Thereby generating company can arrange the procurement documents with better and can choose a provider that better anyway. In addition, some spares generation mostly brought in from outside the industry. With the capabilities of the current CSTP, CSTP engineering team has been able to reverse engineer on spares is strategically located in the power sector, a gas turbine blade. This is done with the support of intelligent patent to ensure that the activities of reverse engineering can be done without violating the intellectual property rights provisions.

Other potential customer segment is the local government. With the government's program to bring up STP and TP in areas opened up opportunities for CSTP to choose a strategic position as a consultant for the planning and construction of STP or TP in the area. In addition, the CSTP can also act as a technology provider in the process of technology transfer of intellectual property and the results of R\&D activities. Another segment that is not less important is the presence of technology incubators in the CSTP.

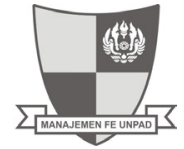

Customer segment for this are budding entrepreneurs based technology. CSTP is equipped with high-tech infrastructure that are arranged in such a way to help these budding entrepreneurs to take advantage of the facilities provided are based on mutual benefit. The facilities were built as state assets can be the mainstay of technology-based start-up entrepreneurs without having to build a fairly expensive investment in the early stages of business.

\section{Value Proposition}

CSTP Value Proposition is a benefit offered to the market segments served. Of course, the value proposition will determine the selected customer segments or otherwise. Value proposition will also affect other components such as the Channel and Customer Relationship. With CSTP current position, CSTP able to provide access to high-tech facilities with the specificity of its infrastructure and facilities. In addition, the CSTP can also provide access to the network and market capitalization by its programs are built.

\section{Channels}

Channels are the means for CSTP is to deliver to Customer Value Proposition segment served. Channel function in several stages starting from customer awareness to after sales service. Two other elements that must be considered carefully in making models Channel is the Value Proposition and Customer Segment.

\section{Revenue Stream}

Revenue Stream is considered the most vital component. Generally, organizations generate revenue from customers. Nonetheless CSTP could open the inflow of income from the pockets not direct customers. This element is an element that can restrict the movement of business CSTP. Rules and regulations applicable to CSTP that exist at the moment requires it to move in accordance with the provisions and regulations in force. Rules and regulations that exist today known as the Tax State Revenue (non-tax). This scheme is a scheme that is not a business-oriented business model is said to be so even if the business model based organization PNBP is not flexible business model. This inflexibility is seen that a percentage of services should not be used directly, and if this is to be done then this 


\section{JURNAL BISNIS \& MANAJEMEN}

ISSN 1412 - 3681

can be considered a violation of law. Within $1 \times 24-$ hour reception service is to be deposited into the state treasury. Another thing that is considered less flexible is when reception service result exceeded the planned non-tax revenues, it should immediately propose a revision to the provisions that require time not immediately. It is perceived to be less of a problem if it were amendments predictable and adequate revision time and not going beyond the end of the revision. However, if excess reception is not allowed time to be revised, then the best way is to refuse service. It is of course a paradox if viewed from the perspective of service. Moreover, when the value of service relatively large value, a problem arises is the initial capital to do the job very limited. On the other hand, CSTP as government agencies are not allowed to make a loan to another party so that it could be seen as more inflexibility.

Attempts to overcome this inflexibility is being conducted by the CSTP to consider implementing the Financial Management of Public Service Agency (BLU PPK). PPK BLU is as stated in Government Regulation No. 23 of 2005 and amendments to the Government Regulation No. 74 of 2012 provides the necessary flexibility as an issue at the top in an effort to improve service to the community.

\section{Customer Relationship}

Customer Relationship namely CSTP way to bond with its customers.

\section{Key Activities}

Key Activities are the main activities CSTP to be able to create the Value Proposition.

\section{Key Resources}

Key Resources are resources that belong CSTP used to realize the value proposition. Generally tangible human resources, technology, equipment, channel and brand.

\section{Key Partnership}

Key Partnership is a source of power required by the CSTP to realize the value proposition, but not owned by the organization. Utilization Key Partnership by the company may take the form of outsourcing, joint venture, joint operation, or strategic alliances.
Jurnal Bisnis \& Manajemen, 2018, Vol. XIX, No. 1, 47-58

Available at: http://journal.feb.unpad.ac.id/index.php/jbm

\section{Cost Structure}

Cost Structure is the composition of the cost to operate CSTP realize the value proposition provided to customers. Efficient cost structure is the key of the profits earned CSTP organization.

Based on survey results and in-depth interviews, then the arrangement diagram BMC - CSTP that can be proposed are as follows:

\begin{tabular}{|c|c|c|c|c|}
\hline \multirow[t]{2}{*}{$\begin{array}{l}\text { Key } \\
\text { Partnerships } \\
1 . \\
\text { Stakeholders } \\
2 . \\
\text { Local } \\
\text { Governance } \\
\text { 3. Star-up } \\
\text { Company } \\
\text { 4. Tenant } \\
\text { 5. } \\
\text { Shareholders } \\
\text { 6. Supplier } \\
\text { 7. Media }\end{array}$} & $\begin{array}{l}\text { Key } \\
\text { Activities } \\
\text { 1. Service } \\
\text { operation } \\
2 . \\
\text { Promotion } \\
\text { 3. Training } \\
\text { 4. } \\
\text { Production } \\
\text { 5. } \\
\text { Distribution }\end{array}$ & $\begin{array}{l}\text { Value } \\
\text { Proposition } \\
\text { 1. Physical } \\
\text { Asset } \\
\text { 2. } \\
\text { Organizational } \\
\text { Culture } \\
\text { 3. Service } \\
\text { Quality } \\
\text { 4. To expand } \\
\text { or increase } \\
\text { the Value } \\
\text { Proposition } \\
\text { (something } \\
\text { new) }\end{array}$ & $\begin{array}{l}\text { Customer } \\
\text { Relationships } \\
\text { 1. Personal } \\
\text { Assistance } \\
\text { 2. Flexible } \\
\text { Cost } \\
\text { 3. Automati } \\
\text { on }\end{array}$ & \multirow[t]{2}{*}{$\begin{array}{l}\text { Customer } \\
\text { Segments } \\
\text { 1. New } \\
\text { Entrepreneur } \\
\text { 2. Star-Up } \\
\text { Company } \\
\text { 3. Business } \\
\text { Community } \\
\text { 4. SMEs }\end{array}$} \\
\hline & $\begin{array}{l}\text { Key } \\
\text { Resources } \\
\text { 1. Human } \\
\text { Resources } \\
\text { 2. Physical } \\
\text { Resources } \\
\text { 3. } \\
\text { Marketing } \\
\text { Tim } \\
\text { 4. Trainer }\end{array}$ & & $\begin{array}{l}\text { Channels } \\
1 . \\
\text { Offline } \\
2 . \\
\text { Online }\end{array}$ & \\
\hline \multicolumn{2}{|c|}{$\begin{array}{l}\text { Cost Structure } \\
\text { 1. Human Resources, } \\
\text { Payroll, Training, } \\
\text { Supporting Cost } \\
\text { 2. Operational cost } \\
\text { 3. Promotion } \\
\text { 4. Main Asset } \\
\text { 5. Maintenance }\end{array}$} & \multicolumn{3}{|c|}{$\begin{array}{l}\text { Revenue Streams } \\
\text { 1. Services charges } \\
\text { 2. Royalty } \\
\text { 3. Equity } \\
\text { 4. New Revenue Streams From Additional } \\
\text { Value Proposition }\end{array}$} \\
\hline
\end{tabular}

Figure 3. Business Model Canvas for CSTP

Once all the boxes in the Business Model Canvas CSTP filled, the next is a discussion about the results of the business model. From here it was possible to be modified if one another box already match or not? if the cost is too much? where? get any revenue that can improve in each box? if that could be removed, or plus-item-item in the box? All possibilities can be dynamic in accordance with existing conditions. Each business development CSTP will be more easily detected with ease and can be modified by quickly.

Based on the results of the discussion, blue ocean strategy and future business model canvas in the CSTP can be formulated that:

First, CSTP can bring change to the business are services that are typically service becomes segmented market (based on the 
Jurnal Bisnis \& Manajemen, 2018, Vol. XIX, No. 1, 47-58

Available at: $h$ ttp://journal.feb.unpad.ac.id/index.php/jbm

type of company and the ability of its resources) and diversified market (customer demand to be served directly and indirectly);

Second, The CSTP has innovated element value propositions in terms of newness (add science and technology in the business), performance (lack of human resources proportionately), customization (customer can request in accordance with her wishes), getting the job done (customer can request services certain to follow the capabilities of its resources), price (quite reasonably priced), risk reduction (the CSTP warranty ministry with certain conditions), accessibility (not all SMEs are able to buy services CSTP because of the level of resources each SME is different and perception the price for each SME, but all parties were able to access to this CSTP) and usability (CSTP services easy to apply).

Third, CSTP the direct customers reach (meet directly and face to face (channels themselves) and indirect (recommendations from other parties outside the CSTP (stakeholder partner channels). CSTP through all phases of channels; awareness (stakeholders about the innovations that have been done are not direct), evaluation (to help customers evaluate value propositions CSTP), purchase (CSTP explain what should be done by the customer to receive service), delivery (delivering value proposition to customers by way of explaining about the type of services CSTP it) and after sales (warranty in case of dissatisfaction with service CSTP).

Fourth, Category customer relationships that are applied in the CSTP is personal assistance (customer communicate directly with employees and managers (STP), dedicated personal assistance (special customer served by top management CSTP), communities (CSTP managers create discussion groups to connect with its customer community).

Fifth, Sources of income derived from services CSTP. The price mechanism used is flexible price (the price set by the MoU).

Sixth, Key resources within the CSTP categorized in three things: physical (physical facility that is counter, intellectual (brands and partnerships), human (employees), and financial.

Seventh, CSTP perform production and incubation services. The most important activity in a relationship with the customer is the CSTP should be friendly and honest, always explain how the quality, the advantages and disadvantages of the CSTP services as well as learn to see which model is suitable for the customer.

Eighth, Key Partnerships; types of partnerships that exists between CSTP with his partner is joint ventures (CSTP can develop new business) and customer-supplier relationships to ensure the supply of reliable power source (the relationship between the manager and the customer and supplier CSTP well). Partners contributed most to the CSTP that supplier (in operation, CSTP aided by the supplier takes care of everything from capital goods up to a relationship).

Ninth, Cost Structure; CSTP included in class cost-driven business model and value driven. Characteristics of the cost
ISSN 1412 - 3681

structure CSTP is divided into four, namely fixed costs (salaries of personnel, costs over head, the cost of equipment, the cost of non-operational) and variable costs (services, modules and prototypes, transportation costs), economies of scale (at a certain moment in which services increases, the operational costs incurred will tend to decline) and economies of scope (services that are sold not just a single model / product alone, but various models / products are combined in one region, where it caused a scope greater so the costs should be used to extend the reach of business to be down).

\section{CONCLUSION}

A simple formula to start a business is the revenue must be greater than the cost, or the income is greater than the costs incurred. Indeed, it seemed simple, but many cases it happens that many companies are already establish more than 15 years' experience difficulties because simply, one calculates spending, many costs that are not counted in the end cost is greater than revenue, and not least also the habit of organization business bit by bit using the company's operational cash unnoticed. In this case, CSTP main focus when creating BMC to do is take into account the Revenue to Cost.

Based on the results of the discussion about the current business model canvas and blue ocean strategy, it can be concluded that the CSTP can bring change for businesses that generally mass market becomes segmented. CSTP has the innovation capacity element value propositions in terms of newness, performance, getting the job done, design, risk reduction, accessibility and usability.

\section{RECOMMANDATION}

Based on the analysis of Blue Ocean Strategy and Future Business Model Canvas CSTP, it can be recommended as follows;

First, Develop customer segment of CSTP to the market that is diversified;

Second, Should improve value propositions available today taking into account the expectations of consumers;

Third, Improve range through its own channel to improve the performance of personnel within reach;

Fourt, Maintaining the function of customer relationships;

Fifth, Increase sources of income from other rental services;

Sixth, Improve key resources especially physical facilities and human resources;

Seventh, Establish new customer segments.

\section{REFERENCES}

Adam, C. (2012). The ABC of Science Parks. Seminars of the Spanish Foundation of Rheumatology, 13 (3), 85-94.

Albahari, A; Klofsten, M. and Pérez, S. (2011) Managing a Science Park: A Study of Value Creation for Their Tenants. In Proceedings for the Triple Helix IX International Conference, Stanford University. Retrieved from: http://www.leydesdorff.net/th9/Managing\%20 a\%20Science\%20Park\%20A\%20study\%20of\%20 


\section{JURNAL BISNIS \& MANAJEMEN}

ISSN 1412 - 3681

value\%20creation\%20for\%20their\%20tenants.pdf

ANPROTEC (2012).Incubadoras e parques. Associação Nacional de Entidades Promotoras de Emprendimentos Innovadores. [Consulted Dec 2012]. Available in: http://anprotec.org.br/site/incubadoras-e-parques/ perguntas-frequentes/.

APTE (2012). Definition of Park. Asociación de Parques Científicos y Tecnológicos de España (APTE) [Consulted Dec 2012]. Available in: http://www.apte.org/en/ definition-of-park.cfm

Chesbrough, H., Rosenbloom, R.S., (2002). The Role of The Business Model in Capturing Value from Innovation: Evidence from Xerox Corporation's Technology SpinOff Companies. Industrial Aad Corporate Change 11, 529-555.

Figlioli, A., (2011). Financing of Technology Parks Originated from Public-Private Partnerships: Outlining Business Models. In Globelics Academy 2011. University of Tampere.

Government Regulation No. 23 (2005) on Financial Management of Public service Agency.

Government Regulation No. 74 (2012) on Amandment to Government Regulation No. 23 (2005) on Financial Management of Public service Agency.

Hansson, F., Husted, K., \& Vestergaard, J., 2005. Second Generation Science Parks: From Structural Holes Jockeys to Social Capital Catalysts of The Knowledge Society. Technovation, 25(9), 1039-1049.

IASP, (2002). IASP International Board, 6 February 2002.

IASP, (2010). IASP Strategigram Analytical Re-port. Málaga : IASP.

Johnson, M.W., Christensen, C.M., Kagermann, H., (2008). Reinventing your business model. Harvard business review 86, 57-68.

Kang, B., (2004). A Study on The Establishing Development Model for Research Parks. Journal of Technology Transfer, 29, 203-210.

Link, A.N., (2009). Research, Science, and Technology Parks: An Overview of the Academic Literature. In: Wessner CW, editor. Undestanding Research, Science and Technology Parks: Global Best Practice. Report of a Symposium. Committee on Comparative Innovation Policy: Best Practice for the 21st Century. National Research Council. Washington: National Academy Press

Morris, M., Schindehutte, M., Allen, J., (2005). The entrepreneur's business model: toward a unified perspective.
Jurnal Bisnis \& Manajemen, 2018, Vol. XIX, No. 1, 47-58

Available at: http://journal.feb.unpad.ac.id/index.php/jbm Journal of Business Research 58, 726-735.

Ondategui, J.C., (2001). The Science and Technology Parks in Spain: Challenges and Opportunities. General Research Directorate of the Community of Madrid, Madrid, Spain. ISBN 84-451-1954-0.

Osterwalder, A., (2004). The business model ontology: A proposition in a design science approach. Academic Dissertation, Universite de Lausanne, Ecole des Hautes Etudes Commerciales 2.

Osterwalder, A., Parent, C., Pigneur, Y., (2004). Setting up an ontology of business models, in: Proceedings of 16th International Conference on Advanced Information Systems Engineering (CAISE03) Workshops (3). pp. 319-324.

Osterwalder, A., Pigneur, Y., (2002). An e-business model ontology for the creation of new management software tools and IS requirement engineering, in: Proc. Of the CAiSE.

Osterwalder, A., Pigneur, Y., (2003). Modeling value propositions in e-Business, in: Proceedings of the 5th International Conference on Electronic Commerce. pp. 429-436.

Osterwalder, A., Pigneur, Y., (2010). Business Model Generation: A Handbook for Visionaries, Game Changers, and Challengers. John Wiley \& Sons.

Osterwalder, A., Pigneur, Y., others, (2002). An e-business model ontology for modeling e-business, in: 15th Bled Electronic Commerce Conference. pp. 17-19.

Osterwalder, A., Pigneur, Y., Tucci, C.L., (2005). Clarifying Business Models: Origins, Present, and Future of the Concept. Communications of the Association for Information Systems 16, 1.

Osterwalder, A., Pigneur, Y., (2009). Business Model Generation. (T. Clark, Ed.) Amsterdam, Netherlands: Self Published.

Rowe, D., (1987). The University's Role in Assembling Resources to Establish and Develop a Science Park. University of Warwick Science Park.

Sabir M. S., Hameed R. M., Rehman K. \& Rehman I. (2012). Theoretical Foundation of Business Model and Their Building Blocks. Journal of Management Research, 4(4), pp. 160-179.

Shafer, S.M., Smith, H.J., Linder, J.C., 2005. The power of business models. Business horizons 48, 199-207.

The Business Channel. (2016). "The Business Model Canvas - 9 Steps to Creating a Successful Business Model - Startup Tips". https://www.youtube.com/ 
Jurnal Bisnis \& Manajemen, 2018, Vol. XIX, No. 1, 47-58

Available at: http://journal.feb.unpad.ac.id/index.php/jbm watch?v=IPOcUBWTgpY.

UKSPA, (2012). Science Park definition. United Kingdom Science Park Association [consulted Dec 2012]. Available in: http://www.ukspa.org.uk/about_ukspa/

UNESCO, (1993). University-Industry Partnership. Concept and definition [web]. UNESCO Science Policy; [consulted 2013]. Available in: http://www.unesco.org/new/ en/natural-sciences/science-technology/universityindustry-partnerships/unispar-programme/conceptand-definition/.
JURNAL BISNIS \& MANAJEMEN

ISSN 1412 - 3681

Wang, L., Jaring, P. Wallin, A., (2009). Developing a Conceptual Framework for Business Model Innovation in the Context of Open Innovation In: Third IEEE International Conference on Digital Ecosystems and Technologies.

Zott, C., Amit, R., \& Massa, L. (2011). The Business Model: Recent developments and future research. Recuperado el Octubre de 2011, de Wharton University of Pennsylvania-Management Department- Journal of management: http://wwwmanagement.wharton.upenn.edu/amitresearch/ docs/2011/BusinessModelRecDevs_Amit-Zott_ JoM2011.pdf. 